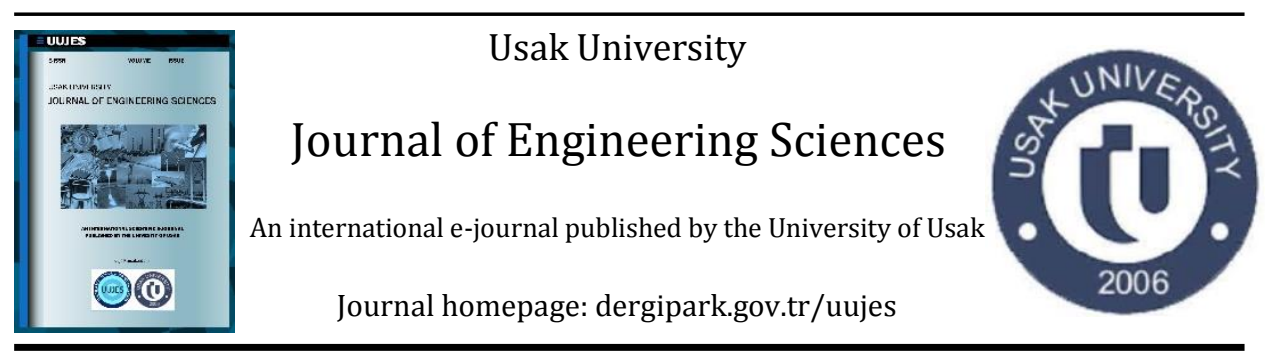

Review article

\title{
EVALUATION OF ELECTRIC POWER PLANTS AND PRODUCTION CAPACITY IN TURKEY
}

\author{
Murat Kabakcl* \\ Mugla Sitkı Kocman University, Faculty of Science, Department of Physics, Mugla, Turkey \\ Received: 6 August $2020 \quad$ Revised: 9 Nov $2020 \quad$ Accepted: 8 Dec 2020 Online available:28 Dec 2020 \\ Handling Co-Editor: Jülide Öner
}

\begin{abstract}
In this study, Turkey's current installed capacity of power plants and plants number distribution were studied. Over time, the methods developed for energy demand and the statistical evaluation of the existing resource potential in installed power have been made. Initially, electricity was produced by thermal and hydroelectric power plants. Although production diversity has increased recently with the use of renewable energy sources, Turkey is a dependent country on foreign energy. In addition, recent studies indicate that Turkey's demand for energy will increase further. To meet the increasing demand, the construction of two nuclear power plants is ongoing. Besides, electric energy production continues with wind and solar power plants. The ratio of solar power plants in total production has increased from $0.3 \%$ to $1.4 \%$ in the last five years, and the ratio of wind power plants in total production has increased from $2.6 \%$ to $3.8 \%$. As a result, the policies to be followed in determining the production methods in the upcoming periods are discussed and suggestions are presented.
\end{abstract}

Keywords: Electric energy; thermic power plants; solar power plants; wind power plants; geothermal power plants.

(C)2020 Usak University all rights reserved.

\section{Introduction}

Energy is defined as the ability of an object or system to do work and is of great importance for all countries in the world. Besides, it plays an important role in countries' having a strong political, economic and cultural structure. Energy consumption rate is seen as a factor showing the economic growth and development levels of countries [1]. Among the energy types, electrical energy is the most used and demanded energy type globally. Population growth, developing technology and industrialization can be shown as important factors in increasing demand [2]. Especially, energy demand of developed and

*Corresponding author: Murat Kabakcl

E-mail: mrtkbkc@gmail.com (ORCID ID: 0000-0002-9234-0058)

DOI: $10.47137 /$ uujes.777706

(C)2020 Usak University all rights reserved. 
developing countries are shown growing faster than other countries. Developed countries are defined as countries which have been made the industrial revolution. These types of countries consume more electricity to produce. In addition to traditional methods, new energy production methods are being investigated in order to meet the increasing demand in developed countries [3]. These methods can be listed like thermal power plants, hydroelectric power plants, nuclear power plants, natural gas, wind turbines, solar power plants and geothermal resources [4].

Geographical features of countries and underground resources are an important factor in determining the production method. For example, countries with high amount of underground resources such as hard fossil fuels may prefer thermal power plants, Today, energy production and consumption rates of countries differ according to their level of development. Countries, which have low energy production, are dependent on other countries to meet their energy needs. This means that currency outflow from the country and also foreign dependency in energy. Such countries set policies to increase the rate of production.

After the Oil Crisis in 1973, the researches has been begun for alternative sources that could be used instead of fossil fuels. In addition, the release of harmful gases from the use of fossil fuels into the atmosphere causes air pollution. Energy obtained from natural sources such as sun, wind, wave, and geothermal are defined as renewable (alternative) energy [5]. The sun is the world's largest source of energy. In addition, the lack of reserves and environmental damage are also important advantages. The advantages of solar energy have caused the sun to be used and popularized in electricity generation [6].

Turkey, is working on energy production to reduce energy imports. The Ministry of Energy Natural Resources has recently been promoting the use of renewable (alternative) energy sources in electricity generation. In addition, it is aimed to reduce the dependency on foreign countries by increasing the use of domestic resources in electricity production. In this way, foreign currency outflow from the country is reduced and economic gain is achieved.

\section{Electric power generation resources}

Turkey's demand for electricity continues to increase. To meet the increasing demand, the installed power capacity has been continuously increased over time. In the first years of its establishment, production was provided from coal fossil fuels power plants and hydroelectric power plants. Recently, solar power plants, wind power plants and geothermal resources have also been used. It is planned to increase the resource diversity with the nuclear power plants planned to be opened in the coming period. Turkey's installed production capacity is $45 \mathrm{MWh}$ in 1923 and this value had increased to $500 \mathrm{MWh}$ in 1950. In addition, it is planned to increase the production capacity to the next level with the newly established power plants. Statistical distribution of the existing installed power and the resources used was provided by the Ministry of Energy and Natural Resources of the Republic of Turkey.

According to the data of the Ministry of Energy and Natural Resources of the Republic of Turkey, electrical energy consumption increased by $2.2 \%$ compared to 2018 and reached to 304.2 billion $\mathrm{kWh}$, and electrical energy production increased by $2.2 \%$ compared to 2018 to 304.8 billion kWh.

In $2018,37.3 \%$ of electricity generation was produced from coal, $29.8 \%$ from natural gas, $19.8 \%$ from hydroelectric energy, $6.6 \%$ from wind, $2.6 \%$ from the sun, $2.5 \%$ from geothermal and $1.4 \%$ from other sources. 


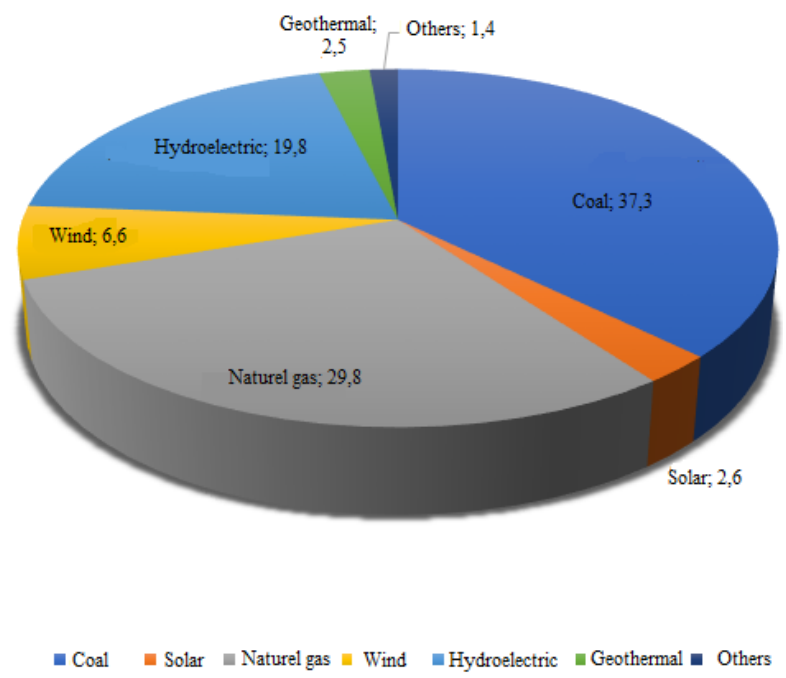

Fig. 1 Turkey's distribution of electrical energy production source (2018)

According to the data of the Ministry of Energy and Natural Resources of the Republic of Turkey; 2019 September data shows that Turkey's current installed power plant capacity increased to $90720 \mathrm{MW}$.

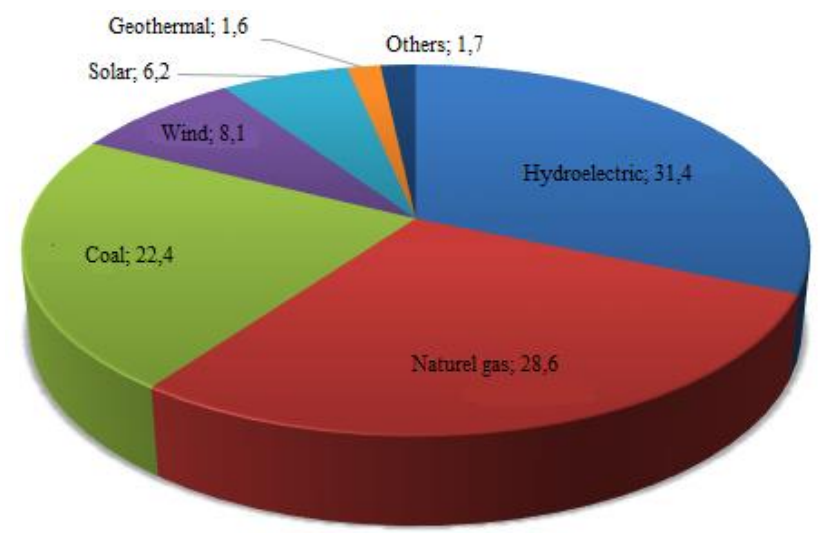

Fig. 2 Turkey's installed power plant capacity of percentage distribution according to sources (September, 2019)

According to the data of the Ministry of Energy and Natural Resources of the Republic of Turkey, as of September 2019, the number of power plants in our country has reached 8069. 
Table 1 Total installed electric energy power plant number in Turkey (September, 2019)

\begin{tabular}{ccccccccc}
\hline $\begin{array}{c}\text { Power } \\
\text { plant } \\
\text { type }\end{array}$ & Hydroelectric & $\begin{array}{c}\text { Naturel } \\
\text { gas }\end{array}$ & Coal & Wind & Solar & Geothermal & Others & Total \\
\hline $\begin{array}{c}\text { Power } \\
\text { plant } \\
\text { number }\end{array}$ & 669 & 330 & 68 & 262 & 6435 & 52 & 253 & 8069 \\
\hline
\end{tabular}

Statistics show that the diversity of resources in production has increased. The number of solar power plants is higher than the number of other power plants and this indicates that the investment in solar power plants is high. Short, medium and long term energy need forecasts should be made and emergency policies should be established. According to studies, it is predicted that energy demand will increase by $60 \%$ in the world in 2030 compared to 2017 and $100 \%$ in our country. Long-term energy production policies should be revised, existing power plants should be regularly maintained and renewable power plants should be supported to meet demand. The investor can be encouraged with the Build - Operate - Transfer model. Safety, quality and economy are important factors in meeting energy demand. In addition, it is necessary to make plans for the transmission and development of the generated electricity. To carry out the studies a regular basis, Turkey Electricity Authority, Turkey Electricity Distribution Corporation, Turkey Electricity Generation Company, Electricity Generation Company, Turkey Electric Transmission Company, Turkey Electricity Trading and Contracting Company and the Energy Market Regulatory Authority was established. In this way, institutional structuring has started.

\subsection{Renewable energy resources and production capacities}

Using different sources in electrical energy production is very important in terms of diversifying the production. The fact that the production depends on a single source may create disruptions in the event of the unexpected error and accident that the requested energy is given to the system. In addition, the shortage of resources used in the power plant over time causes a decrease in production. For this reason, the use of different sources of production in energy production can prevent problems that may occur. The resource reserve to be used in production should be analyzed in detail and the decision should be made according to the results obtained. For example, the establishment of thermal power plants in regions with high fossil fuel reserves, hydroelectric power plants in regions rich in streams and dams, solar power plants in areas with high sunshine duration and irradiation amount, and wind power plants in areas with high wind speed would be the correct power plant in terms of energy production.

Turkey's electric energy was supplied from thermal power plants until 1950's. It is a solid substance that contains elements such as carbon, hydrogen and oxygen in the structure of coal used in thermal power plants [7]. By 1980's, thermal and hydroelectric power plants became almost equal [4]. 
Table 3. Turkey Electricity Generation (MW)

\begin{tabular}{cccc}
\hline Years & Thermic (MW) & Hydroelectric (MW) & Total (MW) \\
\hline 1925 & 33.3 & 0.1 & 33.4 \\
1930 & 74.8 & 3.2 & 78 \\
1935 & 121.2 & 5.0 & 126.2 \\
1940 & 209.2 & 7.8 & 217 \\
1945 & 237.7 & 8.2 & 245.9 \\
1950 & 389.9 & 17.9 & 407.8 \\
1955 & 573.5 & 38.1 & 611.6 \\
1960 & 860.5 & 411.9 & 1272.4 \\
1965 & 985.4 & 505.1 & 1490.5 \\
1970 & 1509.5 & 725.4 & 2234.9 \\
1975 & 2407 & 1779.9 & 4186.6 \\
1980 & 2987.9 & 2130.8 & 5118.7 \\
1985 & 5229.3 & 3874.8 & 9104.1 \\
1990 & 9535.8 & 6764.3 & 16270.1 \\
1995 & 11074 & 9862.8 & 20936.8 \\
2000 & 16052.5 & 11175.2 & 27227.7 \\
2005 & 25917.3 & 12926,2 & 38843,5 \\
2010 & 32278,5 & 17245,6 & 49524,1 \\
\hline
\end{tabular}

With the development of new methods for energy generation, solar power plants, wind power plants and geothermal power plants have been established. Although the studies focus on renewable energy sources that do not have a shortage of reserves, power plants that produce using coal, lignite, fuel oil and natural gas continue their production.

$47.2 \%$ of the world's natural gas reserves are in the Middle East and 1.7\% in Europe.

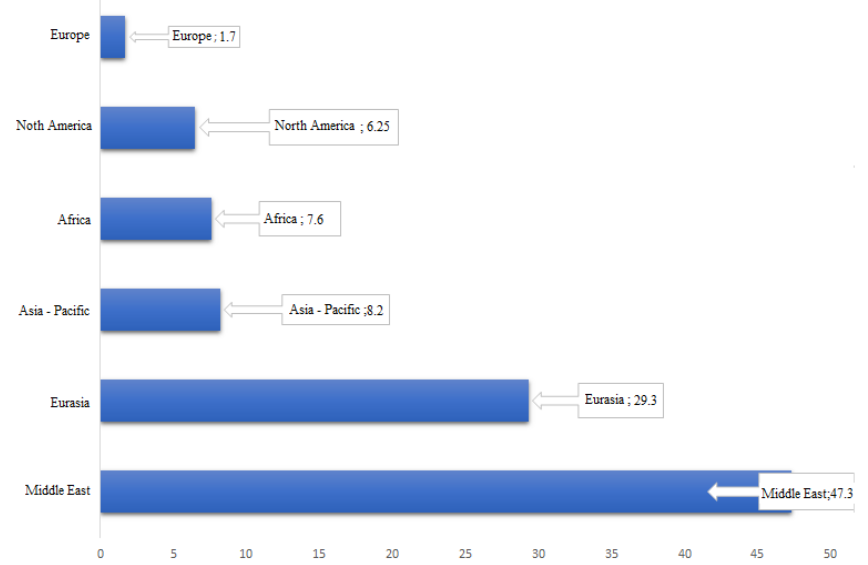

Fig. 3 Percentage distribution of world natural gas reserve rates

The use of natural gas in Turkey was initiated in 1987. Consumption amount in this year is 500 million cubic meters. This value increased to 46 billion cubic meters in 2017. Turkey, among OECD countries, demand for natural gas is the country with the greatest increase. According to recent datas, the demand natural gas which is used in power plants and contributes to the installed power has been reduced [3]. The imported natural gas is mostly used for heating and electrical energy production. Using geothermal 
resources in building heating and using the sun and wind in the production of electricity will reduce the use of natural gas.

In power plants producing coal-based electricity, coal reserve work should be well planned prospectively. In such plants, electricity is produced by burning coal as fuel. $34.8 \%$ of the World coal reserves are in Europe - Eurasia, 32.3\% in Asia Pacific, $27.5 \%$ in North America, 3.7\% in Africa - Eastern Mediterranean and 1.6\% in Central and South America [3].

With technological developments, coal consumption in coal-fired power plants is decreasing. One of the main reasons for the decrease in usage is that the gases released as a result of the burning of coal pollute the atmosphere. These gases play an important role in climate change in the world. It is planned to reduce the rate of gas emitted into the atmosphere by reducing the use of coal. Despite all these disadvantages, the number of power plants producing coal-based electrical energy is in the first place. The decrease in the number of power plants producing coal-based electricity in the coming periods is very important in terms of preventing environmental pollution. Establishment of power plants that use renewable energy sources in place of such plants will provide a great advantage in terms of decreasing environmental pollution and lack of reserve problems.

In Turkey, 10 pieces using imported coal, coal-fired 2 units, 26 lignite-fired units, asphaltites are 1-fired thermal power plant. The total installed power of thermal power plants using coal, lignite and asphaltite fuel is $17316 \mathrm{MW}[3,4]$. In case existing plants continue production, using local coal instead of imported coal is very important in terms of both economic and to decrease foreign dependency. Turkey's geographical structure is suitable for HPP. Hydroelectric power plants have an important place in MENR's energy policy. It should activate the existing capacity both through the public and private sectors, and dependency on foreign countries should be reduced. All these developments show that HEPPs have an important place in meeting the energy needs. In the next period, it should be ensured that the HEPPs are completed in suitable geographies and the ratio of the installed power is increased.

Biogas obtained from animal and organic wastes attracts attention as a solution that directly affects rural development as well as with its economic and environmental features. In Turkey, 82 Biogas, Biomass Power Plant are available. The total installed power of these power plants is $467.37 \mathrm{MW}$.

Hot water in geothermal sources is used to generate electrical energy. Low temperatures between $20-70{ }^{\circ} \mathrm{C}$, medium temperatures between $70-150{ }^{\circ} \mathrm{C}$ and temperatures greater than $150{ }^{\circ} \mathrm{C}$ in geothermal sources are called high temperature values $[3,8]$. Medium and high temperature geothermal resources are used in electrical energy production. Available resources; 79\% are in Western Anatolia, $8.5 \%$ are in Central Anatolia, $7.5 \%$ are in Marmara, $4.5 \%$ are in Eastern Anatolia and $0.5 \%$ are in other regions. Turkey's existing geothermal resource potential; it is the seventh in the world and the first in Europe. 94\% of these resources are low and medium temperature sources and are used for heating, thermal tourism and minerals. The remaining $6 \%$ are suitable for use in electricity generation. Turkey, with its geographical location, has a value of about $31500 \mathrm{MW}$ geothermal potential [8]. The natural gas consumption rate can be reduced by encouraging the use of geothermal resources instead of natural gas in building heating in the Western Anatolia region. In addition, new resource research should be continued and existing resources should be used to the maximum.

Wind is called a renewable energy source and there is no shortage of resource reserves. Electricity is produced by making use of the wind with a certain height and speed. The coastal areas of our country and the Central Anatolia region are suitable for the Wind 
Power Plant (WPP) installation. In this regard, Turkey's wind energy potential map was removed and the wind potential of each city was determined in detail. As a result of the studies and incentives, the installed power of WPPs increased from 146.3 MW to 6106.05 MW between 2007 and 2016 [12]. With the increase of installed power, both the demanded energy is met and the use of renewable energy sources is increased. As RESs use renewable resource, they do not harm and pollute the nature.

The sun is the world's largest source of energy. It is very important to use such a large resource in the production of electrical energy. Solar energy is converted into electrical energy with solar panels. By combining photovoltaic panels, Solar Power Plants (SPP) are created. Recently, countries such as China, America, India, and Japan have started to produce electricity by making significant investments in SPP installation.

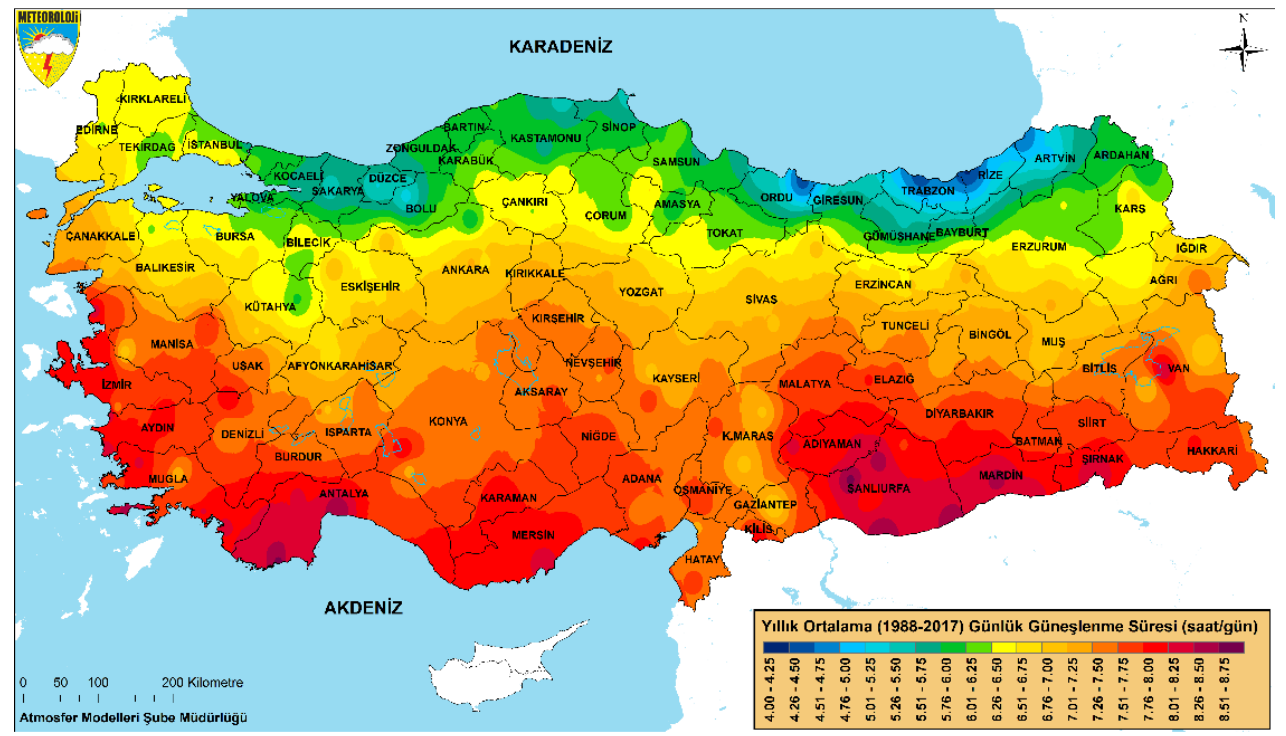

Fig. 4 Turkey's 1988-2017 annual average sunshine duration (hours/day)

According to the Turkey's sunshine duration map; The potential of solar energy is higher in the Southeastern and western parts of the Mediterranean, Southeastern Anatolia, Aegean Region, and Eastern Anatolia Region compared to other regions.

The average annual total sunshine duration is 2640 hours, the average daily sunshine duration is 7.2 hours, and the average total radiation intensity is $311 \mathrm{kWh} / \mathrm{m}^{2}$ - year. Recently, MENR has attached great importance to GES in energy policies, research on this issue has been increased and investors have been encouraged. In current solar power plants, while 0.1 TWh energy was produced in 2014, this value increased to 5 TWh in 2019. Similarly, while 8 TWh electricity was produced in wind power plants in 2014, 15 TWh electricity was produced in 2019 [6]. 


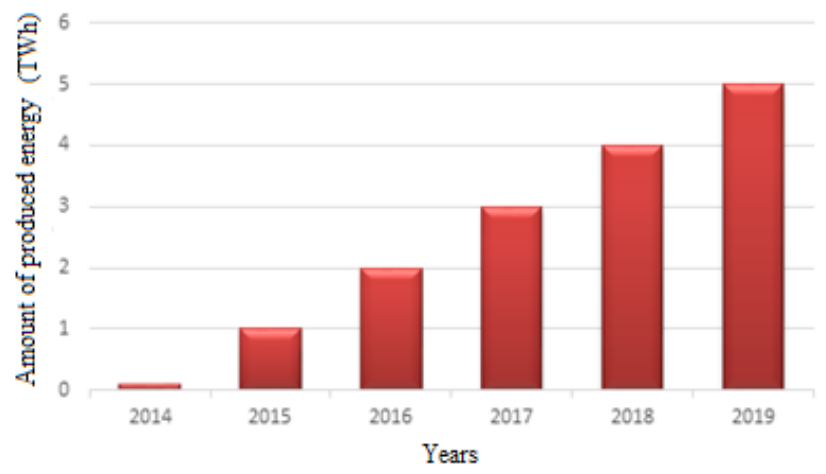

Fig. 5 Distribution of the amount of electrical energy produced in Solar Power Plants by years [6]

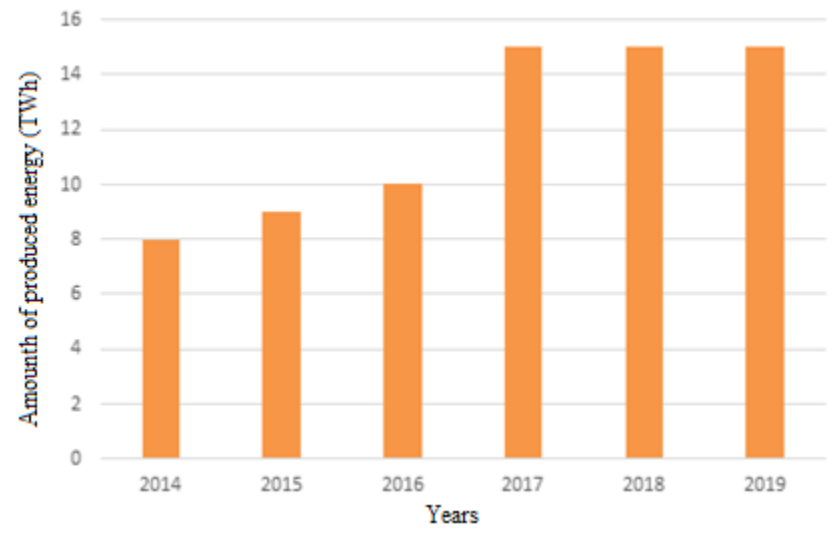

Fig. 6 Distribution of the amount of electrical energy produced in Wind Power Plants by years [6]

\section{Turkey's Installed Capacity Analysis}

Turkey's installed capacity at the end of 2018 that $88551 \mathrm{MW}$, this value has increased to 91267 MW at the end of 2019. According to December 2019 data, 49.1\% of the power plants producing electricity consist of renewable energy sources $[9,10]$.

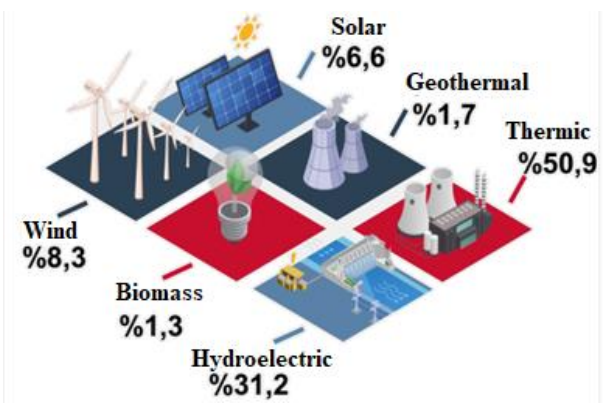

Fig. 7 Installed power distribution in December 2019 [9] 


\subsection{Electric energy production and consumption analysis}

According to December 2019 data, approximately 26.2 TWh of electricity is produced. This value increased to 27 TWh in January 2020 . While $66.2 \%$ of the electricity produced in December 2019 was supplied from thermal power plants, this value decreased to $63.7 \%$ in January 2020. Production value of wind power plants, which had a $7.1 \%$ production rate in December 2019, increased to 8.8\% in January 2020 [9,11]. In 2019, gross electricity consumption throughout the country is 303.7TWh. In 2018, this value was at the level of 304.2 TWh. The reason for the decrease in consumption can be shown as the slowdown in the industry.

\section{Results and Discussion}

In this study, Turkey's electricity production - consumption rate and the current production capacity of the plants were examined. In addition, recent energy policies and practices have been evaluated. Researches show that world energy demand is constantly increasing year by year. The energy needs of developed countries, especially in industry and production, such as the USA, the UK, Germany and France, have increased more than other countries. Such countries produce more to meet their energy needs. They also plan their investments to increase production. Countries that concentrate their energy policies on production reduce dependence on foreign energy and this also means less foreign currency outflow from the country.

Since electric energy is the most demanding type of energy, energy has been produced by traditional methods to meet the demand in the past. In particular, production has been carried out in power plants that use hard coal and lignite, and today production continues in these plants. Although such power plants produce energy, they also have disadvantages such as resource reserve and environmental pollution. Gases $\left(\mathrm{CO}_{2}, \mathrm{CO}\right.$, $\mathrm{SO}_{2}$ ) released as a result of combustion of fuels such as hard coal and lignite used in the power plants cause air pollution. Such gases are defined as greenhouse gases and shown as one of the main causes of climate change. Despite the use of filters in the chimneys of power plants that are producing to prevent the release of harmful gases, the release of gases into the atmosphere cannot be completely prevented. The production capacities of power plants producing electrical energy with traditional methods should be reduced over time and the use of renewable (alternative) energy sources should be increased. In this way, both the resource reserve problem and the damage to the atmosphere are reduced to a minimum. Power plants that produce energy using renewable (alternative) energy sources do not cause environmental pollution since they use natural resources. Low production efficiency is one of the disadvantages of renewable power plants. In the upcoming period, studies should be directed towards increasing the production efficiency of renewable power plants. With the increase of production efficiency, the ratio of power plants producing with traditional methods will decrease in total production. In this way, less harmful gas is released into the atmosphere and environmental pollution is reduced.

Countries should make their energy policies on increasing the number of power plants which is using renewable energy sources. It is expected that the amount of greenhouse gases in the atmosphere will decrease with the increase in the installed power of renewable energy sources. In addition, the renewable energy plants to be established depending on the geographical characteristics of the countries will decrease their dependency on foreign energy.

Turkey was using the traditional method for the production of electrical energy in the past. In the last 10 years, it has promoted renewable (alternative) power plants by adding them to energy policies. In this way, some of the amount of energy demanded is provided 
from these plants. In the establishment of the power plants, domestic and foreign investors were encouraged to increase the number of plants. Aegean and Central Anatolia, wind, sun in the Southern region, the Black Sea and Southeastern Anatolia, hydropower, Western Aegean and Marmara in the geothermal resources, it shows that Turkey is located in a rich region in terms of renewable energy sources. In the coming years, Turkey should increase the variety of resources to reduce dependence on foreign energy.

In the thermal power plants that continue production, it is necessary to carry out new field studies in addition to the use of domestic coal, and to establish HPP from dams and streams in accordance with their geological structure. regions with high solar energy potential, establishment of SPP will increase production power. By using more of geothermal resources in building heating, natural gas consumption can be reduced. With the Nuclear Power Plant (NPP) that is planned to be established, the energy diversity will be increased when energy production starts.

Finally, Turkey's wave, biogas, tides, the detection of hydrogen and other renewable energy sources available to meet the estimated energy demand.

\section{References}

1. Sefer K. Güneș tarlası ile elektrik enerjisi üretimi ve SDÜ kampüs alanında bir uygulama analizi, MSc Thesis, Süleyman Demirel University Department of Mechanical Education, Isparta, Turkey, 2002.

2. Celal K. Güneș ve rüzgar enerjisinden elektrik enerjisi üretimi sistemi tasarımı, MSc Thesis, Selcuk University Institute of Science, Konya, Turkey, 2012.

3. Erdal TK ve Mehmet RT. Türkiye de Elektrik Enerjisi, Siyaset, Ekonomi ve Toplum Araștırmaları Vakfı [Document on the Internet]; 2017 [cited 2017 Month Day]. Available from: https://www.setav.org/rapor-turkiyede-elektrik-enerjisi/

4. Yalçın K. Türkiye' de Elektrik Enerjisi Üretimi; 1994. p. 53 - 77. (Kitapsa yayınevi adi)

5. Şevki ÇÇ. Fotovoltaik paneller yardımı ile güneş enerjisinden elektrik enerjisi üretiminin maliyet analizi ve gelecekteki projeksiyonu, MSc Thesis, Yıldız Technical University Institute of Science, Istanbul, Turkey, 2010.

6. Seda C. Türkiye' de güneş enerjisinden elektrik üretim potansiyelinin belirlenmesi, MSc Thesis, General Directorate of Economic Sectors and Coordination, Istanbul, Turkey, 2017.

7. Yelda Ö. Farklı kömür yakıtları ile elektrik enerjisi üretimi ve yakıt performansının yapay zeka yöntemi kullanılarak saptanması, PhD Thesis, Marmara University Institute of Science, Istanbul, Turkey, 2006.

8. Abdullah CA. Jeotermal enerji kullanılarak termoelektrik jeneratörlerle elektrik enerjisi üretimine etki eden faktörlerin incelenmesi, MSc Thesis, Afyon Kocatepe University Institute of Science, Afyon, Turkey, 2017.

9. Can H and Emre Y. Aylık Enerji Bülteni, Report, TSKB Economic Research, Istanbul, Turkey, 2020.

10. İlknur A. Yenilenebilir enerji kaynaklarından elektrik enerjisi üretiminin belirleyicileri: Türkiye örneği, MSc Thesis, Eskişehir Anadolu University Institute of Social Sciences, Eskişehir, Turkey, 2019.

11. Utkucan Ş. Türkiye elektrik enerjisi üretiminde kullanılacak yakıt alternatiflerinin analitik şebeke yöntemi ile değerlendirilmesi. MSc Thesis, Muğla University Institute of Science, Mugla, Turkey, 2010. 
12. Özgür G. Elektrik enerjisi üretiminde rüzgar ile nükleer enerji kaynaklarının maliyet yönünden karşılaştırılması, MSc Thesis, Marmara University Institute of Social Sciences, Istanbul, Turkey, 2010.

13. Vedat Ş. Türkiyenin elektrik enerjisi üretiminde yenilenebilir enerji kaynaklarının ANP ile modellenmesi ve analizi, MSc Thesis, Gazi University Institute of Science, Ankara, Turkey, 2010.

14. Niyazi B, Türkiye' nin elektrik enerjisi üretimindeki dışa bağımlılığın azaltılması için uygulanması gereken politikalar. Journal of Science and Technology, 2016;4(2):145154. 